\title{
Molecular Flexibility of Longer n-Alkoxy Tail Group Operated Mesomorphism
}

\author{
Vinay.S.Sharma ${ }^{1}$ and R.B. Patel ${ }^{*}$ \\ Chemistry Department, K.K. Shah Jarodwala Maninagar Science College, Gujarat University, \\ Ahmedabad, Gujarat, India \\ Email Corresponding Author address:- \\ vinaysharma3836@gmail.com, \\ roshanpatel770@gmail.com
}

Keywords: Thermotropic, Liquid Crystals, Nematic, Smectic, Enantiotropic.

\begin{abstract}
A novel homologous series RO- $\mathrm{C}_{6} \mathrm{H}_{4}-\mathrm{CH}=\mathrm{CH}-\mathrm{COO}-\mathrm{C}_{6} \mathrm{H}_{4}-\mathrm{CO}-\mathrm{CH}=\mathrm{CH}-\mathrm{C}_{6} \mathrm{H}_{4}-$ $\mathrm{OC}_{16} \mathrm{H}_{33}$ (n) para of chalconyl ester derivatives have been synthesized and studied with a view to understand and establish the effect of molecular structure on thermotropic liquid crystalline state of the substances and to provide novel liquid crystal (LC) materials to the researchers working in an unique multidisciplinary LC state of the substances. A novel chalconyl ester series consists of thirteen $\left(\mathrm{C}_{1}\right.$ to $\mathrm{C}_{18}$ ) homologues. $\mathrm{C}_{5}$ to $\mathrm{C}_{18}$ homologues are enantiotropically nematogenic without exhibition of smectogenic property, while the rest of the $\mathrm{C}_{1}$ to $\mathrm{C}_{4}$ homologues are nonliquid crystals (NLC). Transition temperatures and textures were determined by polarizing optical microscopy (POM) equipped with a heating stage. Textures of a nematic phase are threaded or schlieren. $\mathrm{Cr}-\mathrm{I} / \mathrm{N}$ and $\mathrm{N}-\mathrm{I}$ transition curves of a phase diagram behaved in normal manner except negligible abnormality at $\mathrm{C}_{14}$ homologue. Odd-even effect is exhibited by N-I transition curve. Analytical and Spectral data supported molecular structures of the homologues. Thermal stability for nematic is $97.33^{\circ} \mathrm{C}$ and the degree of mesomorphism vary maximum $24.0^{\circ} \mathrm{C}$ at $\mathrm{C}_{5}$ homologue to minimum $11.0^{\circ} \mathrm{C}$ at $\mathrm{C}_{10}$ homologue respectively. Latent transition temperatures (LTT) are determined for nonmesomorphic homologues $\mathrm{C}_{4}\left(90^{\circ} \mathrm{C}\right)$ and $\mathrm{C}_{3}\left(114^{\circ} \mathrm{C}\right)$ homologues by extrapolation method of transition curve. LC properties of a novel series are (thermometric) compared with structurally similar series.
\end{abstract}

\section{INTRODUCTION}

The study of liquid crystal (LC) state of chalconyl ester derivatives have found probable their applications in LC devices [1,2,3] and pharmaceutical preparation due to their anti-microbial activity $[4,5,6,7,8]$. Thus, present investigation is planned with a views to understand and establish the effects of molecular structure $[9,10,11,12]$ on thermotropic mesomorphism and to avail the novel chalconyl derivatives to the pharma and medicinal chemist for the study of antimicrobial activity in lyotropic condition for the benefit of mankind. Hence, chalconyl ester derivatives consisting of three phenyl rings bonded through $-\mathrm{CH}=\mathrm{CH}-\mathrm{COO}-$ and $-\mathrm{CO}-\mathrm{CH}=\mathrm{CH}-$ central groups and two flexible terminal end groups viz. $-\mathrm{OR}$ and $-\mathrm{OC}_{16} \mathrm{H}_{33}$ will be synthesized and their thermotropic data will be evaluated by an optical polarizing microscopy (POM). Some selected members of a homologous series will be characterized by elemental analysis, IR spectra and ${ }^{1} \mathrm{H}$ NMR spectra. Then the thermotropic behaviours of novel series will be compared with structurally similar other series. Number of homologous ester series with $-\mathrm{CH}=\mathrm{N}-,-\mathrm{N}=\mathrm{N}-,-\mathrm{COO}-\mathrm{CH}_{2}-$, $\mathrm{CH}=\mathrm{CH}-\mathrm{CO}$ - etc. central bridges have been reported till the date $[13,14,15,16,17,18,19,20]$. The results of novel investigation will be discussed and interpreted in terms of molecular rigidity and flexibility $[21,22,23,24,25]$. The group efficiency order will be derived on thermal data. 


\section{EXPERIMENTAL}

\section{Synthesis:}

4-n-Alkoxy Cinnamic acids were synthesized by the method followed by Patel and Doshi [26] from 4 -Hydroxy cinnamic acid as prepared by refluxing 4-hydroxy Benzaldehyde and Malonic acid in pyridine and few drops of piperidine. 4- Hydroxy Cinnamic acid was alkylated using suitable alkylating Agent (R-X) to convert it into 4-n- alkoxy Cinnamic acids (A) prepared by modified method of Dave and Vora [27]. $\alpha$ - 4- hydroxyl benzoyl $\beta-4$ - Hexadecyloxy phenyl ethylene (B) was prepared by usual established method. Esters were synthesized by a literature method [28]. Thus, the Chalconyl - ester homologue derivatives were filtered, washed with sodium bicarbonate solution, dried and purified till constant transition temperatures using an optical polarizing microscope equipped with a heating stage. 4-hydroxy cinnamic acid, Alkyl halides, 4hydroxy benzaldehyde, Malonic acid, piperidine, 4-hydroxy acetophenone, dicyclohexyl carbodimide, Dimethyl amino pyridine, DCM, MeOH, Acetone required for synthesis were used as received except solvents which was dried and distilled prior to use. The synthetic route to a series is mentioned in Scheme-1.

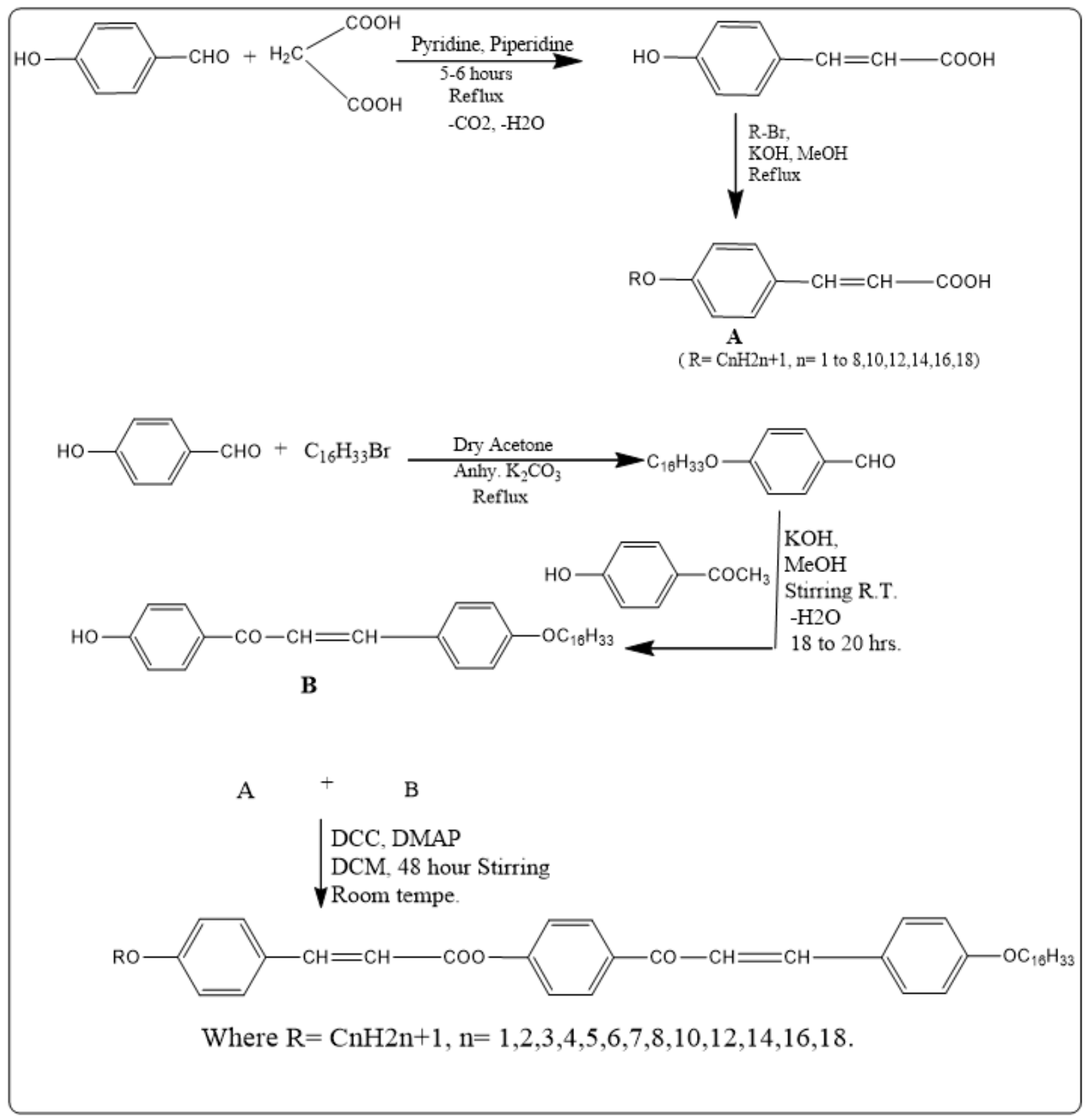

Scheme 1: Synthetic route to the series 


\section{Characterization}

Selected members of the novel homologous series were characterized by Elemental Analysis, infra-red spectroscopy, ${ }^{1} \mathrm{H}$ NMR spectra. IR spectra were recorded by Perkin-Elmer spectrum GX, ${ }^{1} \mathrm{H}$ NMR spectra were recorded on Bruker using $\mathrm{CDCl}_{3}$ as solvent. Microanalysis was performed on a Perkin-Elmer PE2400 CHN analyzer. Transition temperature and LC properties (Textures) were determined using an optical polarizing microscopy equipped with a heating stage. Textures of nematic phase determined by miscibility method.

\section{ANALYTICAL DATA}

Table 1: Elemental Analysis for (1) Octyloxy (2) Decyloxy (3) Dodecyloxy and (4) Octadecyloxy derivatives

\begin{tabular}{|c|c|c|c|c|c|}
\hline \multirow{2}{*}{ Sr. No. } & \multirow{2}{*}{} & Molecular formula & \multicolumn{2}{|c|}{$\begin{array}{c}\text { Elements \% } \\
\text { found }\end{array}$} & \multicolumn{2}{c|}{$\begin{array}{c}\text { Elements \% } \\
\text { Calculated }\end{array}$} \\
\cline { 3 - 6 } & & $\mathrm{C}$ & $\mathrm{H}$ & $\mathrm{C}$ & $\mathrm{H}$ \\
\hline 1 & $\mathrm{C}_{48} \mathrm{H}_{66} \mathrm{O}_{5}$ & 79.72 & 9.01 & 79.77 & 9.14 \\
\hline 2 & $\mathrm{C}_{50} \mathrm{H}_{70} \mathrm{O}_{5}$ & 79.35 & 9.26 & 80.00 & 9.33 \\
\hline 3 & $\mathrm{C}_{52} \mathrm{H}_{74} \mathrm{O}_{5}$ & 80.06 & 9.47 & 80.20 & 9.51 \\
\hline 4 & $\mathrm{C}_{58} \mathrm{H}_{86} \mathrm{O}_{5}$ & 80.52 & 9.85 & 80.74 & 9.97 \\
\hline
\end{tabular}

IR Spectra in $\mathrm{cm}^{-1}$ for Butoxy \& Octadecyloxy Derivatives:

Butoxy : 663 ( $\mathrm{Cis}-\mathrm{CH}=\mathrm{CH}-)$, 640 Polymethylene $\left(-\mathrm{CH}_{2}-\right)$ n of $-\mathrm{OC}_{4} \mathrm{H}_{9}, 823(-\mathrm{C}-\mathrm{H}-\mathrm{def}$. $m$ disubstituted-Para), 734 Polymethylene $\left(-\mathrm{CH}_{2}-\right)$ of $-\mathrm{OC}_{16} \mathrm{H}_{33}, 937$ (-C-H- def. hydrocarbon), 1022(C-O-) Str, 1168,1251 and 1384 ( $-\mathrm{C}-\mathrm{O}$ str in $-\left(\mathrm{CH}_{2}\right)$ n chain), 1450 and 1469 (-C-H- def. in $\left.\mathrm{CH}_{2}\right)$, 1510 ( $-\mathrm{C}=\mathrm{C}-)$ str, 1602 and 1728 (-C=O group) and (-COO- ester group), 2848 and 2945(-C-H str in $\mathrm{CH}_{3}$ ).

Octadecyloxy : 663( $\mathrm{Cis}-\mathrm{CH}=\mathrm{CH}-), 713$ Polymethylene $\left(-\mathrm{CH}_{2}-\right)$ n of $-\mathrm{OC}_{18} \mathrm{H}_{37}, 831$ ( $-\mathrm{C}-\mathrm{H}-$ def. $\mathrm{m}$ di-substituted-Para), 734 Polymethylene $\left(-\mathrm{CH}_{2}-\right)$ of $-\mathrm{OC}_{16} \mathrm{H}_{33}, 937$ (-C-H- def. hydrocarbon), 1069 (-C-O-) Str, 1390, 1153 and 1248 ( $-\mathrm{C}-\mathrm{O}$ str in $-\left(\mathrm{CH}_{2}\right)$ n chain, $1450\left(-\mathrm{C}-\mathrm{H}-\right.$ def. in $\left.\mathrm{CH}_{2}\right), 1510$ ( $-\mathrm{C}=\mathrm{C}-)$ str, 1600 and 1672 (-C=O group) and (-COO- ester group), 2850 and 2920 (-C-H str in $\left.\mathrm{CH}_{3}\right)$.

\section{${ }^{1} \mathrm{HNMR}$ spectra in $\mathrm{CDCl}_{\mathbf{3}}$ in $\boldsymbol{\delta} \mathrm{ppm}$ for Pentoxy \& Tetradecyloxy Derivative:}

Pentoxy: $0.87\left(\mathrm{t},-\mathrm{CH}_{3}\right.$ of $\left.-\mathrm{C}_{5} \mathrm{H}_{11}\right), 1.2-1.4\left(\mathrm{~m}\right.$, n-poly methylene groups of $\left.-\mathrm{OC}_{5} \mathrm{H}_{11}\right), 1.78(\mathrm{~m}, \mathrm{n}-\mathrm{poly}$ methylene groups of $\left.-\mathrm{OC}_{16} \mathrm{H}_{33}\right), 3.5-3.7\left(\mathrm{~s},-\mathrm{OCH}_{2}-\mathrm{CH}_{2}\right.$-of $\left.\mathrm{OC}_{16} \mathrm{H}_{33}\right), 4.02\left(\mathrm{~s},-\mathrm{OCH}_{2}-\mathrm{CH}_{2}-\mathrm{of} \mathrm{OC}_{5} \mathrm{H}_{11}\right)$ $6.51(\mathrm{~d},-\mathrm{CH}=\mathrm{CH}-)$ 6.9-7.4 (s,-CO-CH=CH), 8.09 (s, p-substituted phenyl ring).

Tetradecyloxy: $0.87\left(\mathrm{t},-\mathrm{CH}_{3}\right.$ of $\left.-\mathrm{C}_{14} \mathrm{H}_{29}\right), 1.2-1.5\left(\mathrm{~m}, \mathrm{n}\right.$-poly methylene groups of $\left.-\mathrm{OC}_{14} \mathrm{H}_{29}\right), 1.80(\mathrm{~m}$, n-poly methylene groups of $\left.-\mathrm{OC}_{16} \mathrm{H}_{33}\right), 3.9\left(\mathrm{~s},-\mathrm{OCH}_{2}-\mathrm{CH}_{2}-\right.$ of $\left.-\mathrm{OC}_{16} \mathrm{H}_{33}\right), 4.01\left(\mathrm{~s},-\mathrm{OCH}_{2}-\mathrm{CH}_{2}\right.$-of $\left.\mathrm{OC}_{14} \mathrm{H}_{29}\right), 6.81(\mathrm{~d},-\mathrm{CH}=\mathrm{CH}-)$ 6.9-7.5(s,-CO-CH=CH), 7.87(s, p-disubstituted phenyl ring).

Table 2: Texture of Nematic Phase of $\mathrm{C}_{5}, \mathrm{C}_{10}, \mathrm{C}_{14}, \mathrm{C}_{16}$ by miscibility method.

\begin{tabular}{|c|c|c|}
\hline Sr. No. & Homologue & Texture \\
\hline 1 & $\mathrm{C}_{5}$ & Threaded \\
\hline 2 & $\mathrm{C}_{10}$ & Threaded \\
\hline 3 & $\mathrm{C}_{14}$ & Schlieren \\
\hline 4 & $\mathrm{C}_{16}$ & Schlieren \\
\hline
\end{tabular}




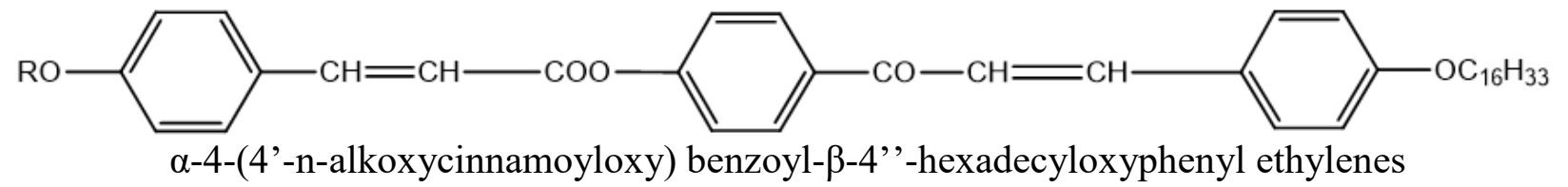

Table 3: Transition Temperature of Homologous series

\begin{tabular}{|c|c|c|c|c|}
\hline \multirow[t]{2}{*}{ Sr.no } & \multirow[t]{2}{*}{$\mathrm{R}=\mathrm{n}$-alkyl group } & \multicolumn{3}{|c|}{ Transition temperatures in ${ }^{0} \mathrm{C}$} \\
\hline & & Smectic & Nematic & Isotropic \\
\hline 1 & $\mathrm{C}_{1}$ & - & - & 135.0 \\
\hline 2 & $\mathrm{C}_{2}$ & - & - & 129.0 \\
\hline 3 & $\mathrm{C}_{3}$ & - & - & 125.0 \\
\hline 4 & $\mathrm{C}_{4}$ & - & - & 112.0 \\
\hline 5 & $\mathrm{C}_{5}$ & - & 84.0 & 108.0 \\
\hline 6 & $\mathrm{C}_{6}$ & - & 78.0 & 96.0 \\
\hline 7 & $\mathrm{C}_{7}$ & - & 86.0 & 101.0 \\
\hline 8 & $\mathrm{C}_{8}$ & - & 82.0 & 98.0 \\
\hline 9 & $\mathrm{C}_{10}$ & - & 88.0 & 99.0 \\
\hline 10 & $\mathrm{C}_{12}$ & - & 82.0 & 94.0 \\
\hline 11 & $\mathrm{C}_{14}$ & - & 84.0 & 101.0 \\
\hline 12 & $\mathrm{C}_{16}$ & - & 78.0 & 92.0 \\
\hline 13 & $\mathrm{C}_{18}$ & - & 70.0 & 87.0 \\
\hline
\end{tabular}

\section{RESULT AND DISCUSSION}

Mesogenic property is induced by linking nonmesogenic component $\alpha$-4-hydroxy benzoyl $\beta$-4'-hexadecyloxy phenyl ethylene (m.p. $102^{\circ} \mathrm{C}$, yield. $72 \%$ ). Mesomorphism commences from $\mathrm{C}_{5}$ homologue and continued upto the last $\mathrm{C}_{18}$ homologue, as enantiotropically nematic with absence of smectogenic character. $\mathrm{C}_{1}$ to $\mathrm{C}_{4}$ homologues are nonmesogenic. Transition temperatures (Table-3) as determined by POM were plotted against the number of carbon atoms present in n-alkyl chain of the left n-alkoxy terminal end group (-OR). A phase diagram (Figure-1) is obtained by joining like or related points to form $\mathrm{Cr}-\mathrm{I} / \mathrm{N}$ and N-I transition curves, showing phase behaviours of novel series. N-I transition curve exhibited odd-even effect. Transition curves for odd and even homologue members of a present series merged into each other at the $\mathrm{C}_{9}$ homologue and then propagated as a single transition curve from and beyond $\mathrm{C}_{9}$ homologue for higher homologues of longer n-alkyl chain, bonded to first phenyl ring through oxygen atom, keeping $-\mathrm{OC}_{16} \mathrm{H}_{33}$ tail end group unchanged throughout a series. A Cr-I/N transition curve follows a zigzag path of rising and falling tendency as series is ascended with overall falling tendency and behaved in normal manner. The N-I transition curve for even members occupied lower position as compared to odd members transition curve. Odd and even membered transition curves initially descends and ascends respectively upto $C_{9}$ homologue and then descended upto $C_{18}$ homologue after passing through a maxima at $\mathrm{C}_{14}$ homologue. Thus, it behaved in normal manner with negligible abnormality at $\mathrm{C}_{14}$ 
homologue. N-I transition curves for odd and even members are extrapolated $[29,30,31,32]$ to $\mathrm{C}_{3}$ and $\mathrm{C}_{4}$ homologues keeping in view of the trends of the transition curves, to determine and predict the LTT of the nonmesogenic homologues $\mathrm{C}_{3}$ and $\mathrm{C}_{4}$, which are $114^{\circ} \mathrm{C}$ and $90^{\circ} \mathrm{C}$ respectively. Analytical and spectral data confirms the molecular structures of homologues. Textures of nematic phase are threaded or schlieren as determined by miscibility method and directly observed through microscopic observation or texture image.

Homologues series
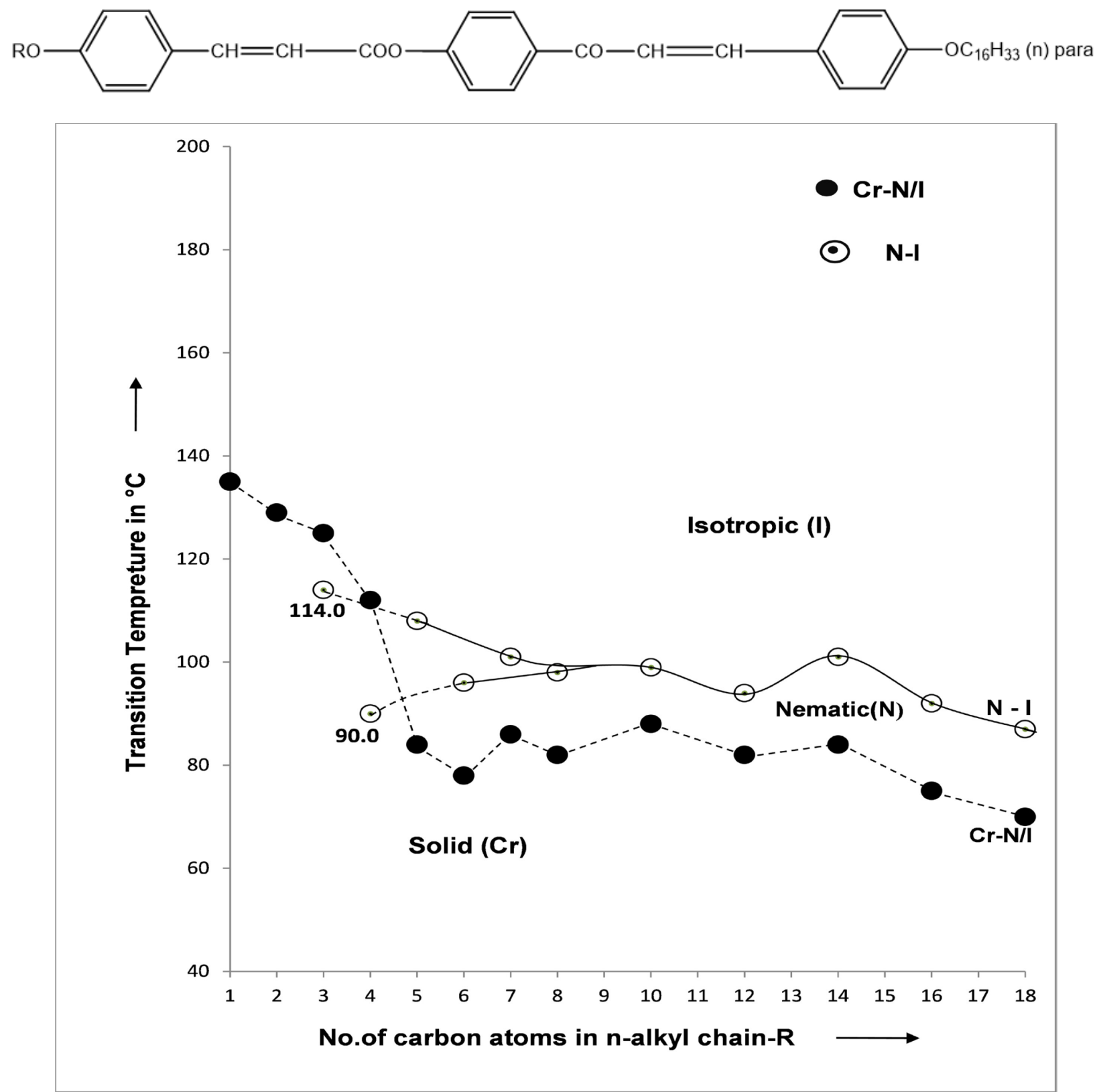

Figure 1: Phase behaviours of Series

The mesogenic thermometric properties from homologue to homologue in the present same series varied with sequential addition of methylene unit or units to left n-alkoxy end group, keeping right sided $-\mathrm{OC}_{16} \mathrm{H}_{33}$ tail group unchanged, as a consequence of changing magnitudes of molecular rigidity and flexibility as series is ascended from homologue to homologue. Some thermometric properties of a present series are compared with the structurally similar other series. The exhibition of nematogenic mesophase formation by $\mathrm{C}_{5}$ to $\mathrm{C}_{18}$ homologues is attributed to the suitable magnitudes of end to end intermolecular anisotropic forces of attractions and closeness as a consequence of favorable molecular rigidity and flexibility resulted from permanent dipolemoment across the long molecular axis, suitable magnitudes of dispersion forces and dipole-dipole 
interactions, molecular polarizability and polarity etc., which facilitate the molecules under microscopic (POM) examination to float on the surface with statically parallel orientational order within definite range of temperature as nematic phase. However, none of the homologue molecules exhibited sliding layered molecular arrangement under floating condition due to inadequate and insufficient intermolecular cohesive forces and closeness to build up layered molecular arrangement in preoccupied crystal lattices in rigid crystalline state prior to exposure of thermal vibrations. Thus, smectogenic mesophase formation is missing throughout the series of present investigation. The absence of either nematic or smectic or any other type of LC state formation is attributed to their high crystallising tendency which arises from low dispersion forces and the low dipole-dipole interactions between instantaneous dipole produced by spontaneous oscillations of electron clouds of the molecules, which induces inability to resist exposed thermal vibrations, causing sharp transition from solid crystalline state to isotropic state without exhibition of an intermediate state of existence, called as LC state.

The exhibition of odd-even effect by N-I transition curve is due to the sequential addition of methylene unit or units which normally appears effective for shorter n-alkyl chain of left n-alkoxy terminal end group. The merging of N-I transition curves for odd and even numbered homologues appears at $\mathrm{C}_{9}$ homologue and then $\mathrm{N}-\mathrm{I}$ transition curve prolonged as single transition curve for longer n-alkyl chain homologues, because of the unusual status of the longer n-alkyl chain of -OR flexible polar group by its coiling or bending or flexibility or coupling with major axis of the core structure of a molecule. The early or late commencement of mesophase depends upon the extent of noncoplanarity of a molecule concerned, depending upon the shape, size and polarities of flexible groups of molecular structures. The probable temperature at which mesophase can persist for nonmesomorphs $\mathrm{C}_{3}$ and $\mathrm{C}_{4}$ are predicted $114^{\circ} \mathrm{C}$ and $90^{\circ} \mathrm{C}$ respectively as monotropic transition temperatures, but their LTTs are not realizable due to their high crystallizing tendency. Low thermal stability and low resistivity towards exposed thermal vibrations are attributed to the low transition temperatures of homologues, bearing longer n-alkyl chain $-\mathrm{OC}_{16} \mathrm{H}_{33}$ at the unchanging tail end group of unusual and unpredictable status under exposed thermal environmental situation. Thus, present homologous series is predominantly nematogenic with low thermal stability ( 97.33) and low thermal resistivity or low degree of mesomorphism. Some mesogenic (LC) properties of presently investigated series are compared with structurally similar other known Series-X [33] and $\mathrm{Y}[34]$ as under in figure-2.

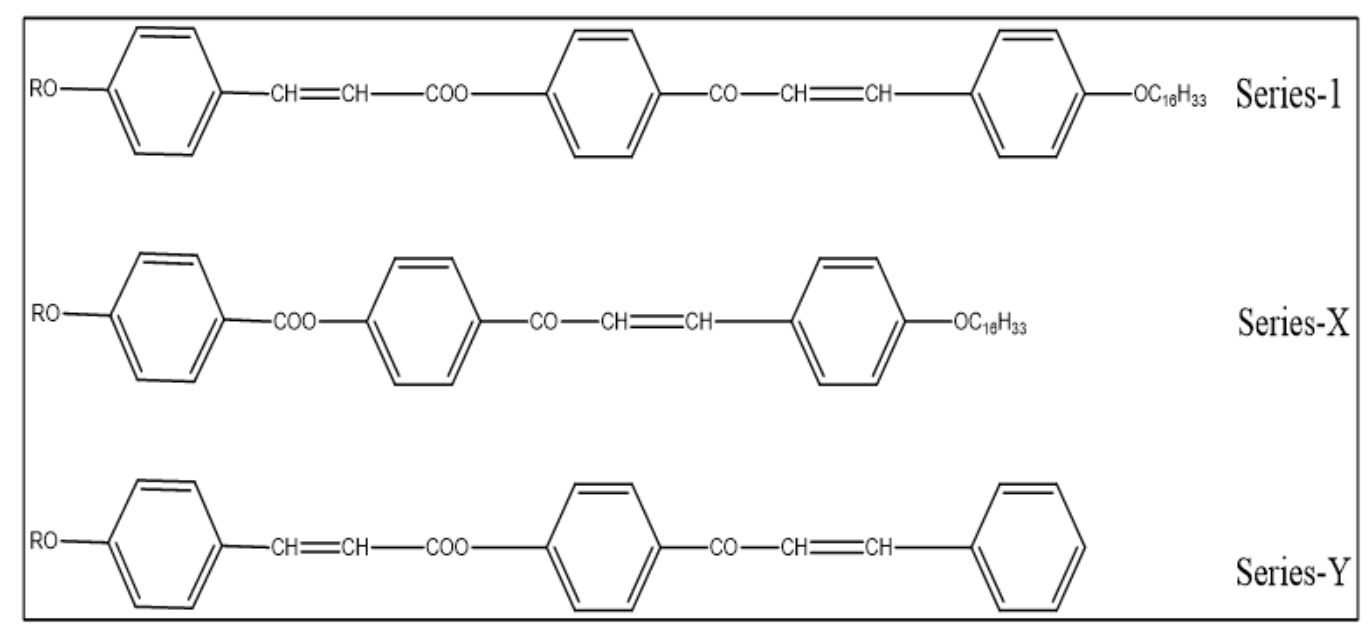

Figure 2: Structurally similar series

Homologous series 1 and series $\mathrm{X}$ are identical with respect to three phenyl rings, one of the central bridges $-\mathrm{CO}-\mathrm{CH}=\mathrm{CH}$ - and the two flexible polar end groups $-\mathrm{OR}$ and $-\mathrm{OC}_{16} \mathrm{H}_{33}$ for the same homologue from series- 1 to series-X, but they differ with respect to first central bridges - COO- and $-\mathrm{CH}=\mathrm{CH}-\mathrm{COO}$ - linking first and middle phenyl rings. Homologous series 1 and $\mathrm{Y}$ are identical in all respect for the same homologue from series-1 to series-Y, except right sided tail end group - 
$\mathrm{OC}_{16} \mathrm{H}_{33}$ and $-\mathrm{H}$ polar group. Therefore, the mesogenic properties and the degree of mesomorphism will depend upon the magnitudes of the differing features of the series- 1 of present investigation and the series-X and $\mathrm{Y}$ chosen for comparison. Following table-3 represents some thermometric properties evaluated from thermal study of the series under comparative study as mentioned below.

Table 3: Relative Thermal Stability in ${ }^{\circ} \mathrm{C}$

\begin{tabular}{|c|c|c|c|}
\hline Series $\longrightarrow$ & Series-1 & Series-X & Series-Y \\
\hline $\begin{array}{l}\text { smectic-isotropic } \\
\text { or } \\
\text { smectic-nematic } \\
\text { Commencement of } \\
\text { Smectic phase }\end{array}$ & - & - & - \\
\hline $\begin{array}{l}\text { Nematic-Isotropic } \\
\text { Commencement of } \\
\text { Nematic phase }\end{array}$ & $\begin{array}{c}97.33 \\
\left(\mathrm{C}_{5}-\mathrm{C}_{18}\right) \\
\mathrm{C}_{5}\end{array}$ & $\begin{array}{c}113.14 \\
\left(\mathrm{C}_{6}-\mathrm{C}_{18}\right) \\
\mathrm{C}_{6}\end{array}$ & $\begin{array}{c}155.4 \\
\left(\mathrm{C}_{5}-\mathrm{C}_{16}\right) \\
\mathrm{C}_{5}\end{array}$ \\
\hline $\begin{array}{l}\text { Total mesophase } \\
\text { length range from } \\
\text { lower to upper }{ }^{0} \mathrm{C} \\
\text { range } C_{i} \text { to } C_{p}\end{array}$ & $\begin{array}{lll}11.0 & \text { to } & 24.0 \\
\mathrm{C}_{10} & & \mathrm{C}_{5}\end{array}$ & $\begin{array}{lll}10.0 & \text { to } & 26.0 \\
\mathrm{C}_{8} & & \mathrm{C}_{10}\end{array}$ & $\begin{array}{lll}11.0 & \text { to } 48.0 \\
\mathrm{C}_{16} & & \mathrm{C}_{5}\end{array}$ \\
\hline
\end{tabular}

Table-3 of present investigation and the homologous series selected for comparative study are

- Nematogenic only with absence of smectic property.

- Mesogenic property commences from $\mathrm{C}_{5}$ or $\mathrm{C}_{6}$ (series-X) homologue.

- Thermal stability for homologous series under comparison progressively enhances from series-1 to series-X to series-Y.

- Lower mesophaselength range of series-1, $\mathrm{X}$ and $\mathrm{Y}$ are almost equivalent, and the upper mesophaselength range progressively increases from series to series.

- Homologous series under comparison exhibited odd-even effect.

Missing of smectogenic property by all the homologous series under comparative study is attributed to the absence of lamellar packing of molecules within preoccupied crystal lattices in a rigid crystals to build up layered structure to cause sliding layered structure under the influence of exposed thermal vibrations due to unsuitable magnitudes of intermolecular lateral anisotropic forces of attractions by low dispersion forces and low dipole-dipole interaction, which fails to show exhibition of smectogenic mesophase. However, end to end anisotropic forces of attractions of suitable magnitudes are sufficient to stabilize and arrange the molecular floating on the surface with stastically parallel orientational order to show nematic mesophase formation only by mesogenic homologues $\mathrm{C}_{5}$ to $\mathrm{C}_{18}$; or $\mathrm{C}_{6}$ to $\mathrm{C}_{18}$ only. The commencement of nematogenic mesophase formation from $\mathrm{C}_{5}$ or $\mathrm{C}_{6}$ homologues indicate the extent of noncoplanarity is identically almost equivalent for the series under comparative study. The increasing order of thermal stabilities from series- 1 to $\mathrm{Y}$ is attributed to the thermodynamical property, heat of formation $(\Delta H)$ associated with each nematogenic homologue of each series, which stabilizes nematogenic mesophase upto isotropic temperature related to thermal resistivity caused by differing magnitudes of flexibility of series 1 and $\mathrm{Y}$ as well as by differing magnitudes of rigidity of series 1 and $\mathrm{X}$ which reflects and vary transition temperature (Isotropic) of homologues. Thus, stabilization of nematic mesophase is facilitated according to thermal resistivity of individual series $1, \mathrm{X}$ and $\mathrm{Y}$. Odd-even effect observed for the series under comparison is attributed to the sequential addition of methylene unit at the left 
n-alkoxy terminal end group - OR, whose variation in the polarity causes variations in mesogenic behaviours of a series.

\section{CONCLUSIONS}

- Homologous series of present investigation is predominantly nematogenic with absence of smectic property whose degree of mesomorphism is low and of low melting type.

- The group efficiency order derived for nematic on the bases of (i) thermal stability (ii) early commencement of nematic phase and (iii) mesophase length range for the same homologue are as under.

(i) Nematic

Series-Y $>$ Series-X $>$ Series-1

(ii) Nematic

Series- $1=$ Series- $Y>$ Series- $X$

(iii) Nematic

Series- $\mathrm{Y}>$ Series- $\mathrm{X}>$ Series-1

- Mesomorphism phenomena are very sensitive and susceptible to molecular structure.

- Combine effect of molecular rigidity and flexibility operates formation of mesophase.

- Present study may be useful to manufacture LC devices and pharmaceutical preparations.

- Present study supports and raises the credibility to the conclusions drawn earlier.

\section{Acknowledgement}

Authors acknowledge thanks to Dr. R. R. Shah, principal of K. K. Shah Jarodwala Maninagar Science College, Ahmedabad. Authors also thank to Dr. A. V. Doshi, Ex-principal of M.V.M. Science and Home Sci. College - Rajkot for his constant support, inspirations and help, as and when needed during the course of present investigation. Authors thank to NFDD Centre for the analytical and spectral services.

\section{References}

[1] F. Reinitzer, Monatsh 9,421,(1888).

[2] W.S.Kim, S.J. Elston, and F.P. Raynes, Display29 (2008) PP.458-463.

[3] E. Hertz, B. Lavorel and O.Faucher, Optical imagine by molecular gas, Nature photon; 5 (2011) PP.783.

[4] ImranTadwee,Dr.Sahanashahi,vivekRamteke,Iftequarsyed, Liquid crystal pharmaceutical Application:A review ,IJPRAS.ISSN2277-2236 vol.1,Issue2(2012),06-11.

[5] G.W. Gray and P.A. Winster (Eds) Liquid Crystal and plastic crystals, chapter-6.2, The role of liquid crystal in life processes by G.T. Stewart, Vol-1,PP.308-326.

[6] Upendra K Jain, Rich K Bhatia, Akkinepally R. Rao, Ranjit singh, Saxsena Ajit K and Seha lrun " Design and Development of Halogenated Chalcone derivatives as potential anticancer Agents “ Tropical Journal of pharmaceutical Research, January 2014: 13(1), 73-80.

[7] Prajkata P. Gaikwad, Desai Maya T.. "Liquid crystalline phase and its Pharma application" International journal of Pharma Research and Review , Dec. 2013; 2 (12); 40-52.

[8] C.A. Calliste, J.C. Le Bail, P. Trouilas, C. Poug, A.J. Chulia, L.J. Duroux, Anticancer, Res. 2001, $21,3949-3956$.

[9] Gray G.W.(1974) ln; Gray G.W. and P.A.Winsor P.A. (eds) liquid crystal and plastic crystals, Chapter-4, Volume-1, PP-103-153.

[10] Gray G.W., Molecular Structure and properties of liquid crystals, Academic press, Landon, 1962.

[11] Gray G.W. and Jones B., Mesomorphism and chemical constitution part-3, The effect of halogen substitution on the 4-Alkoxy benzoic acids, Journal of chemical society (1954) PP, 2556-2562. 
[12] C.T. Imrie, Liq. Crystal dimers. struct. Bond 95 (1999) PP. 149-192.

[13] Dermus D., 100 years of liquid crystals chemistry, mol. Cryst. 165 (1998) PP.45-84.

[14] Dermus D., Plenary lectures 100 years of liquid crystals chemistry, Thermotropic liquid crystals with conventional and unconventional molecular structures, Liq. Cryst, 5 (1998). PP. $75-100$.

[15] lmrie C.T and Luckhrust G.R,, " Liquid Dimers and Oligomers in handbook of Liquid Crystal, law molecular liquid crystals; Vol. 2B, Demus D. , Goodby J.W., Graw G.W., Spiess H. and Vill V. eds, Willey-VCH weinhe 1998, PP-801-833.

[16] Doshi et al (i) Suthar D.M. and Doshi A.V., Mol. Cryst. Liq. Cryst. Vol. 575, PP.76-83. (ii) Chauhan H.N. and Doshi A.V., Mol.Cryst. Liq. Cryst. Vol. 570, PP. 92-100 (2013). (iii) Chaudhari R.P., Chauhan M.L. and Doshi A.V., Vol. 575, PP. 88-95(2013). (iv) Bhoya U.C. , Vyas N.N. and Doshi A.V. , Mol. Cryst. Liq. Cryst., Vol. 552. PP. 104-110. (2012).

[17] Patel B.H. and Doshi A.V. " Synthesis and liquid Crystal Properties of a Nvel Homologous Series 4-(4'-n-Alkoxy benzoyloxy) Benzyl Benzoate" Mol.Cryst. Liq. Cryst., Vol-605, PP.6169 (2015).

[18] Patel B.H. and Doshi A.V. “ Effect of a Central Group on Mesomorphism” Mol. Cryst. Liq. Cryst. Vol-607,PP. 114-122 (2015).

[19] Suthar D.M., Doshi A.A. and Doshi A.V., " Synthesis of liquid crystalline state and evaluation of its properties through a novel Homologous series", Mole. Cryst. Liq. Cryst. Vol-582, PP. 79-87, 2013.

[20] Suthar D.M., Doshi A.A. and Doshi A.V. "Synthesis and evaluation of novel Liquid crystalline Homologous series $\alpha-4-(4$-n-alkoxy Cinnamoyloxy) benzoyl- $\beta-3$ ", 4 "'- Dimethoxy phenyl Ethylenes".Mol. Cryst. Liq. Cryst. Vol. 527, PP.51-58 (2013).

[21] P.A. Henderson, O. Niemeyer, and C.T.Imrie, Methylene-linked liquid crystal dimers, Liq.Cryst. 28 , PP. 463-472(2001)

[22] Hird. M, Toyne. K.J,Gray G.W. , Day S.E. (1993) Liq. Cryst.14, PP. 741.

[23] P.J. Collings and M. Hird (1997), Introduction of Liquid crystals chemistry and Physics, Taylor and Francis Ltd. U.K.1998.

[24] Macros . M, Omenat. A, ,Serrano. J.L and Ezcurra. A(1992), Adv. Matter, 4, 285.

[25] Hird. M, Toyne. K.J,Gray G.W., Day S.E. (1993) Liq. Cryst.14, PP. 741.

[26] Patel R.B. and Doshi A.V. , Der Pharma Chemica,2011,3,(2),PP. 110-117

[27] Dave J.S and Vora R.A (1970). In: J.F . Johnson and R.S. Porter, (eds), ( Liquid Crystals and ordered fluids, Plenum Press: New York, P.447.

[28] Uhood J.A., international Journal of Molecular Science.,vol.12; PP. 3182-3190 (2011).

[29] Bhoya U.C., Vyas N.N. and Doshi A.V. , Mol. Cryst. Liq. Cryst., Vol. 552. PP. 104- 110. (2012).

[30] Doshi A.V., Bhoya U.C., Travadi J.J., Mol.Cryst.Liq.Cryst., Vol. 552. PP. 10-15, (2012)

[31] Lohar J.M and Doshi A.V., " Studies on mixed mesomorphism : Determination of latent transition temperature (LTT) by extrapolation" proceeding of Indian Acad. Of ScienceBangalore, Vol-105, N0-3, June 1993, PP. 209-214.

[32] Ganatara K.J. and Doshi A.V., "Study of binary systems inducing mesophase and determination of latent Transition Temperature". Journal of Indian Chem. Soc., Vol.77, July 2000, PP. 322-325.

[33] Vinay S. Sharma, Ravindra B. Solanki and R.B. Patel, Manuscript of the research paper entitled, "Molecular Structure and Mesomorphism: Effect of Tail/Lateral Group" submitted for publication in Mol. Cryst. Liq. Cryst. Journal with its reference no. LCMH No. 326 date $28^{\text {th }}$ April 2015.

[34] Chauhan H.N., Doshi A.V., Der Pharma Chemica, 4(3): PP. 977-983, (2012) 